ISSN 2083-3725

Volume 11, No. 1, 2018
Authors' contribution/

Wkład autorów:

A. Zaplanowanie badań/

Study design

B. Zebranie danych/

Data collection

D. Interpretacja danych/

Data interpretation

Manuscript preparation

F. Opracowanie

piśmiennictwa/

Literature search

G. Pozyskanie funduszy/

Funds collection
C. Analiza statystyczna/

Statistical analysis

E. Przygotowanie tekstu/

\section{ECONOMIC DEVELOPMENT AND DEPENDENCE THEORY: THE APPROACH OF THE UN ECONOMIC COMMISSION FOR LATIN AMERICA AND THE CARIBBEAN (ECLAC)}

\author{
TEORIA ROZWOJU GOSPODARCZEGO I ZALEŻNOŚCI: \\ PODEJŚCIE KOMISJI GOSPODARCZEJ NARODÓW ZJEDNOCZONYCH \\ DS. AMERYKI ŁACIŃSKIEJ I KARAIBÓW (ECLAC)
}

\section{Osmar Antonio Bonzanini ${ }^{1(A, B, C, D, E, F)}$, Tamara Silvana Menuzzi Diverio ${ }^{1(A, B, C, D, E, F)}$, Luiz Gustavo Zuliani da Silva ${ }^{1(A, B, C, D, E, F)}$, Estevo Mateus Olesiak $^{2(A, B, C, D, E, F)}$}

\author{
${ }^{1}$ Integrated Regional University of Alto Uruguay and the Missions (URI), Brazil \\ Zintegrowany Uniwersytet Regionalny Górnego Urugwaju i Misji (URI), Brazylia \\ ${ }^{2}$ University of the Sinos River Valley (UNISINOS), Brazil \\ Uniwersytet Doliny Rzeki Sinos (UNISINOS), Brazylia
}

Bonzanini O.A., Menuzzi Diverio T.S., Zuliani da Silva L.G., Olesiak E.M. (2018), Economic development and dependence theory: the approach of the UN Economic Commission for Latin America and the Caribbean (ECLAC)/ Teoria rozwoju gospodarczego i zależności: podejście Komisji Gospodarczej Narodów Zjednoczonych ds. Ameryki Łacińskiej i Karaibów (ECLAC). Economic and Regional Studies, Vol. 11, No. 1, pp. 20-33. https://doi.org/10.29316/ers-seir.2018.02

\section{Summary}

ORIGINAL ARTICLE

Subject and purpose of work: The purpose of this article is to present the vision of ECLAC - Economic Commission for Latin America and the Caribbean and its contribution to the reflections on economic development.

JEL code: B22

Materials and methods: This is an exploratory and descriptive study. The first part of the paper contemplates the emergence and evolution of ECLAC thinking during its more than sixty-five years of

Submitted:

November 2017

existence. The second deals with dependency theory, ending with the current thinking proposed by ECLAC.

Accepted:

March 2018

Tables: 0

Figures: 0

References: 23

Results: It results in a brief analysis of the moment of the globalization of the economy as an exclusionary process in the history of capitalism, emphasizing the importance of the ECLAC thinking, reinvigorated nowadays.

Conclusions: It is considered that the dependency theory has been the great contribution of ECLAC thinking, with the change of focus from a viewpoint only from the prism of the central countries, to an optic from the point of view of the peripheral countries.

Keywords: ECLAC, development, theory of dependency

\section{Streszczenie}

ORYGINALNY ARTYKUŁ NAUKOWY

Przedmiot i cel pracy: Celem tego artykułu jest przedstawienie wizji ECLAC - Komisji Gospodarczej Narodów Zjednoczonych ds. Ameryki Łacińskiej i Karaibów oraz jej wkładu w rozważania na temat rozwoju gospodarczego.

Klasyfikacja JEL: B22

Materiały i metody: Jest to studium o charakterze badawczym i opisowym. W pierwszej części artykułu podejmowane są rozważania nad pojawieniem się i ewolucją myśli ECLAC podczas ponad sześćdziesięciu pięciu lat jej istnienia. W drugiej części zajęto się teorią zależności, kończąc na obecnej linii rozważań proponowanej przez ECLAC.

Wyniki: Rezultatem niniejszego studium jest krótka analiza etapu globalizacji w gospodarce jako procesu wyłączającego $\mathrm{w}$ historii kapitalizmu, z uwypukleniem znaczenia myśli ECLAC, której w dzisiejszej dobie zyskała nową energię.

Wnioski: Teoria zależności zostaje uznana za wielki wkład myśli ECLAC wraz ze zmianą orientacji poglądowej z takiej która wyraża tylko przekonania państw o kluczowej pozycji na taką która przedstawia poglądy krajów peryferyjnych.

Słowa kluczowe: ECLAC, rozwój, teoria zależności

Address for correspondence/ Adres korespondencyjny: Professor Osmar Antonio Bonzanini (ORCID 0000-0002-8366-5803), PhD in Management, Certified Accountant, Master in Development, Management and Citizenship; Integrated Regional University of Alto Uruguay and the Missions (URI) - Brazil; Street 15 de Novembro, 0877 - 98400-000 - Frederico Westphalen/RS - Brazil; e-mail: bonzanin.prof@gmail.com; tel. +55 55996544439.

Journal indexed in/ Czasopismo indeksowane w: AgEcon Search, AGRO, BazEkon, Index Copernicus Journal Master List, ICV 2016: 92,91; Polish Ministry of Science and Higher Education 2016: 9 points / AgEcon Search, AGRO, BazEkon. Index Copernicus Journal Master List ICV 2016: 92.91; Ministerstwie Nauki i Szkolnictwa Wyższego 2016: 9 punktów. Copyright: (C) 2018 Pope John Paul II State School of Higher Education in Biała Podlaska, Osmar Antonio Bonzanini, Tamara Silvana Menuzzi Diverio, Luiz Gustavo Zuliani da Silva, Estevo Mateus Olesiak. All articles are distributed under the terms of the Creative Commons Attribution-NonCommercial-ShareAlike 4.0 International (CC BY-NC-SA 4.0) License (http://creativecommons.org/licenses/by-nc-sa/4.0/), allowing third parties to copy and redistribute the material in any medium or format and to remix, transform, and build upon the material, provided the original work is properly cited and states its license. 


\section{Introduction}

The problem of development has been presented as a theme of countless debates over time. The issue is not recent and the growing concern of people with living conditions around the world has prompted further discussion. There have been waves of globalization that occurred during the last millennium, the most recent being at the end of the twentieth century and its novelty is due to the fact that it is an event of unparalleled magnitude, covering a broad field of social life and state influence, as well as on the inequality between the North and the South on which it is based and fed. Thus, the sovereignty of weaker states is threatened by international financial agencies and other transnational private actors, such as multinational corporations (Santos 2005).

Discussions on development are classic. However, new ideas have made this debate current and the issue of development passes through freedom, that is, development must be related to the improvement in the quality of life of people and the freedoms they enjoy, thus being able to develop their potentialities (Sen 2000). Thus, development must be analyzed under a distinct bias as opposed to the limiting bias that considers development merely through factors such as Gross Domestic Product (GDP) growth, personal incomes, industrialization, technological advancement, or social modernization.

Social problems require equal attention to economic problems. From the identification of social difficulties, the constraints on development will be overcome and it will become necessary to draw up a development project to define the action plans in search of the aspirated results from the social. Therefore, there is a need to modify the development model to be implemented, aiming to overcome the condition of dependence characteristic of underdevelopment (Furtado 1974). In this way, a development-building project must be made via active political action and that promotes equality and social well-being.

In Latin America, economic dependence on the "First World" countries places the issue of development as a central theme in the search for solutions to reduce social inequalities. In this context, personalities came together to change the course of development in Latin America. As a result, the Economic Commission for Latin America and the Caribbean (ECLAC) emerged, a forum that ended up creating a particular vision of development and underdevelopment from the perspective of the peripheral countries, thus innovating in relation to the traditional thinkers at the time of their emergence, who saw only underdevelopment, characteristic of the countries of the South, as a stage of development. ECLAC, in addition to generating its own analytical approach, was, during its more than sixty-five years of existence, the main source of information and analysis on the economic and social reality of Latin America (Bielsthowsky 2000).

\section{Wstęp}

Problem rozwoju był od zawsze stawiany jako temat niezliczonych debat. Problem ten nie należy do nowych, a rosnąca troska ludzi o warunki życia na całym świecie skłania do dalszej dyskusji. W poprzednim tysiącleciu globalizacja występowała falami, z których ostatnia miała miejsce pod koniec XX wieku a jej nowość polegała na tym, że było to wydarzenie o niespotykanej skali, dotykające rozległego obszaru życia społecznego i państwowego, oraz nierówności między Północą a Południem, na których się opiera i które ją napędzają. Przez to, suwerenność słabszych państw jest zagrożona przez międzynarodowe agencje finansowe i inne międzynarodowe podmioty prywatne, takie jak korporacje międzynarodowe (Santos 2005).

Dyskusje na temat rozwoju należą do stałych punktów publicystyki. Jednak dzięki nowym pomysłom debata ta jest wciąż aktualna, a kwestia rozwoju nawiązuje do problemu wolności. Rozwój musi być powiązany z poprawą jakości życia ludzi i wolności, z której korzystają, dzięki czemu mogą rozwijać swój potencjał (Sen 2000). Tak więc rozwój należy rozpatrywać z innej perspektywy, odmiennej od podejścia ograniczającego, które rozważa rozwój jedynie przy pomocy wskaźników takich jak wzrost produktu krajowego brutto (PKB), dochody osobiste, industrializację, zaawansowanie technologiczne lub modernizację społeczną.

Problemy społeczne wymagają uwagi w takim samym stopniu co gospodarcze. Identyfikacja problemów społecznych doprowadzi do przezwyciężenia ograniczeń rozwoju i koniecznym stanie się opracowanie projektu rozwojowego $\mathrm{w}$ celu zdefiniowania planów działań, dzięki którym osiągnięte zostaną upragnione przez społeczeństwo rezultaty. W związku $\mathrm{z}$ tym istnieje potrzeba modyfikacji modelu rozwoju, który ma zostać wdrożony, a nakierowanego na przezwyciężenie stanu zależności charakterystycznego dla krajów nisko-rozwinietych (Furtado 1974). Zgodnie z tym punktem widzenia, projekt wsparcia rozwoju musi być realizowany poprzez aktywne działania polityczne promujące równość i dobrobyt społeczny.

W Ameryce Łacińskiej zależność gospodarcza od krajów „Pierwszego Świata” powoduje, że kwestia rozwoju staje się głównym powodem poszukiwania rozwiązań zmniejszających nierówności społeczne. Właśnie z myślą o tym znane osobistości połączyły siły, aby zmienić bieg rozwoju Ameryki Łacińskiej. W wyniku tego powstała Komisja Gospodarcza Narodów Zjednoczonych ds. Ameryki Łacińskiej i Karaibów (ECLAC) - forum, którego zwieńczeniem stało się stworzenie szczególnej wizji stanu rozwoju i niskiego stopnia rozwoju z perspektywy krajów peryferyjnych, tym samym wprowadzając innowacje w stosunku do tradycyjnych myślicieli, którzy w czasie jego powstania rozpatrywali jedynie niski stopień rozwoju, charakterystyczny dla krajów Południa, jako etap rozwoju. ECLAC, oprócz stworzenia własnego podejścia analitycznego, stanowiła przez ponad sześćdziesiąt pięć lat swojego istnienia główne źródło informacji i analiz na temat realiów gospodarczych i społecznych Ameryki Łacińskiej (Bielsthowsky 2000). 
In this sense, the objective of this article is to present details of the emergence and evolution of ECLAC's thinking, besides addressing dependency theory. There is, in this text, the purpose of exhausting the theme, but in broadening the discussion and reflections on the subject.

It is worth noting that this article may also be of interest to the European public because the study provides information to scientists aiming to improve the multilateral dialogue and to develop future research on the political, economic and social development of Latin America. The benefit to the scientific community is precisely in the possibility of promoting the discussion of the topic, since to elucidate difficulties is to advance in the debate of development leading to the possibility of reducing economic, political and social problems and contrasts that differentiate the two regions, which consequently would also bring countries. It should be noted that the links between the two continents, besides being cultural and historical, are mainly economic connections, remembering that among the countries that make up Latin America are the most important trading partners of European countries and European companies are among the main investors in countries of Latin America.

\section{Objective and methods of research}

For the elaboration of this research, whose main focus is to present the emergence and evolution of ECLAC's thinking during its more than sixty-five years of existence and, more specifically, to address the theory of dependency and the current relevance of ECLAC, using methods of a qualitative nature that allow an exploratory and descriptive approach through bibliographic and documentary procedures.

"The method is the order that must be imposed on the different processes necessary to achieve a certain end or a desired result" (Cervo, Bervian 2002). Thus, this is accomplished as a set of several steps for conducting the research, such as techniques, scientific procedures used by a particular science to achieve a particular goal.

From the point of view of approaching the problem, this study can be classified as qualitative in nature. The qualitative approach is justified as an adequate way to understand the nature of a social phenomenon (Bhattacherjee 2012). In relation to its objectives, this research is classified as exploratory and descriptive. Emphasizes that exploratory studies allow the researcher to deepen their knowledge around a given problem (Richardson 2017). The exploratory research was developed with the purpose of providing an overview, seeking a closer approximation with the subject, initiating a wider investigation (Beuren 2013).

In turn, the descriptive research allowed establishing relationships between the researched materials and reading documents on the subject, and, with this, a new vision of the problem emerged. Some descriptive research goes beyond the simple
W tym kontekście celem tego artykułu, oprócz omówienia teorii zależności, jest przedstawienie szczegółów powstania ECLAC i ewolucji jej myśli. W założeniu tekst ten ma na celu przedstawienie wyczerpujących informacji na ten temat jak również poszerzenie obszaru dyskusji i przedmiotowych rozważań.

Warto zauważyć, że artykuł ten może również zainteresować europejską opinię publiczną, ponieważ niniejsze studium dostarcza naukowcom informacji mających na celu usprawnienie wielostronnego dialogu i rozwój przyszłych badań nad politycznym, gospodarczym i społecznym rozwojem Ameryki Łacińskiej. Korzyści dla społeczności naukowej polegają właśnie na możliwości promowania dyskusji na ten temat, gdyż wyjaśnianie problemów to osiąganie postępu w debacie nad rozwojem prowadzącym do możliwości zmniejszenia gospodarczych, politycznych i społecznych problemów i kontrastów, które różnicują oba regiony, co w konsekwencji mogłoby doprowadzić do zbliżenia krajów. Należy zauważyć, że powiązania między tymi dwoma kontynentami są nie tylko kulturowe i historyczne, ale również gospodarcze. Należy pamiętać, że wśród krajów tworzących Amerykę Łacińską są najważniejsi partnerzy handlowi krajów europejskich, a firmy europejskie są głównymi inwestorami w krajach Ameryki Łacińskiej.

\section{Cel i metody badań}

W celu opracowania tych badań, dla których głównym założeniem jest przedstawienie okoliczności powstania ECLAC i ewolucji jej sposobu myślenia w ciągu ponad sześćdziesięciu pięciu lat jej istnienia, a dokładniej, podjęcie problemu teorii zależności i obecnego znaczenia ECLAC, z wykorzystaniem metod o charakterze jakościowym, które umożliwiają podejście badawcze i opisowe za pomocą procedur bibliograficznych i dokumentacyjnych.

„Metoda jest porządkiem, który należy nałożyć na różne procesy niezbędne do osiągnięcia określonego celu lub pożądanego rezultatu" (Cervo, Bervian 2002). Stąd też, dokonuje się tego poprzez kilka etapów prowadzenia badań, takich jak techniki, procedury naukowe stosowane przez daną gałąź nauki z zamiarem osiągnięcia określonego celu.

Z punktu widzenia podejścia do problemu, studium niniejsze można zaklasyfikować jako jakościowe. Podejście jakościowe jest uzasadnione jako odpowiedni sposób na zrozumienie natury zjawiska społecznego (Bhattacherjee 2012). W odniesieniu do swoich celów, studium niniejsze klasyfikuje się jako badawcze i opisowe. Trzeba podkreślić tutaj, że studium badawcze pozwala badaczowi pogłębić wiedzę na temat danego problemu (Richardson 2017). Badania odkrywcze zostały opracowane w celu przedstawienia ogólnego zarysu, poszukiwania dokładniejszego przybliżenia tematu, rozpoczęcia szerszego badania (Beuren 2013).

$\mathrm{Z}$ kolei badania opisowe pozwoliły na ustalenie zależności pomiędzy badanymi materiałami a dokumentami na ten temat i wraz z tym pojawiła się nowa wizja problemu. Niektóre badania opisowe wykraczają poza prostą identyfikację istnienia związku między zmien- 
identification of the existence of a relationship between variables, intending to determine the nature of this relationship, approaching explanatory research (Bhattacherjee 2012).

In the context of the technical procedures, the research can be classified as bibliographical and documentary. As a result of the bibliographic research, in this study, we sought to have a better understanding of the subject from studies already performed and published, such as theses, dissertations and scientific articles in the study area. For the secondary data, bibliographic sources were used as searches in books, magazines, articles and other updated publications.

\section{Results and discussions}

\section{Emergence and evolution of ECLAC thinking}

ECLAC is one of the five economic commissions of the United Nations (UN), which aims to induce the development of the Region in the medium and long term. Established on February 25, 1948, by Resolution 106 of the Economic and Social Council and approved by the UN General Assembly after the end of World War II. Created to monitor the policies aimed at promoting the economic development of the Latin American region, to advise the actions directed to its promotion and to contribute to strengthen the economic relations of the countries of the area, both with each other and with the other nations of the world. Subsequently, its work was extended to the Caribbean countries and the objective of promoting social and sustainable development was incorporated.

From the claims of the Latin American countries to have been excluded from the Marshall Plan a US project after the end of World War II - ECLAC therefore emerged in the context of a polarized world, such as a US strategy to contain the advance of socialist ideas in Latin America. His first works sought to diagnose the specific problems of each country and what hindered their economic development. The tools economists possessed at the time were the Ricardian version of economic growth and the Keynesian instrumental of macroeconomic analysis (Bielsthowsky 2000).

The study of economic development in Latin America gained momentum from the work of Raúl Prebisch, an Argentine economist, who presented a new political approach and became the basis of ECLAC thinking (Bielsthowsky 2000). Prebisch is considered the father of the structuralist theory of economic development, whose theory came to the developing world, viewing Latin America as something apart.

Prebisch's conception of the center-periphery system was based on the fact that the economic relations between the developed countries, treated as the center of the world capitalist economy, and the underdeveloped countries, treated as periphery, were characterized by unequal exchanges, in higher countries' specialization in industrial products, nymi, mając na celu określenie charakteru tego związku, zwracając się do badań wyjaśniających (Bhattacherjee 2012).

W kontekście procedur technicznych badania można uznać za bibliograficzne i dokumentalne. W wyniku badań bibliograficznych w niniejszym studium poszukiwaliśmy lepszego zrozumienia przedmiotu na podstawie badań już wykonanych i opublikowanych, takich jak prace dyplomowe, rozprawy i artykuły naukowe w przedmiotowej dziedzinie. Jeśli chodzi o dane wtórne, źródła bibliograficzne wykorzystano jako metody wyszukiwania w książkach, czasopismach, artykułach i innych aktualizowanych publikacjach.

\section{Wyniki i dyskusja}

\section{Powstanie i ewolucja poglądów ECLAC}

ECLAC jest jedną z pięciu komisji ekonomicznych Organizacji Narodów Zjednoczonych (ONZ), która ma na celu wywołanie rozwoju Regionu w średnioi długoterminowej perspektywie. Ustanowiono ją w dniu 25 lutego 1948 r. Rezolucją Rady Gospodarczej i Społecznej nr 106 po czym została zatwierdzona przez Zgromadzenie Ogólne ONZ po zakończeniu II wojny światowej. Powołano ją do monitorowania programów politycznych mających na celu promowanie rozwoju gospodarczego Ameryki Łacińskiej, do doradztwa w zakresie działań nakierowanych na jej promocję i do wnoszenia wkładu we wzmocnienie stosunków gospodarczych krajów tego obszaru, zarówno między sobą, jak i z innymi narodami świata. Następnie jej działanie zostało rozszerzone na kraje karaibskie i włączono do niego zadanie promowania rozwoju społecznego i zrównoważonego.

Biorąc pod uwagę zastrzeżenia państw latynoamerykańskich dotyczące ich wykluczenia z Planu Marshalla - amerykańskiego projektu po zakończeniu II wojny światowej - ECLAC pojawiła się więc w kontekście świata spolaryzowanego, takiego jak amerykańska strategia powstrzymania postępów idei socjalistycznych w Ameryce Łacińskiej. Jej pierwsze prace miały na celu zdiagnozowanie specyficznych problemów każdego kraju oraz tego co utrudniało ich rozwój gospodarczy. Narzędzia jakimi dysponowali w tym czasie ekonomiści to ricardiańska wersja wzrostu gospodarczego i keynesowskie narzędzie analizy makroekonomicznej (Bielsthowsky 2000).

Badanie rozwoju gospodarczego w Ameryce Łacińskiej nabrało tempa dzięki pracy Raúla Prebischa, argentyńskiego ekonomisty, który przedstawił nowe podejście polityczne i stał się podstawą linii myślenia ECLAC (Bielsthowsky 2000). Prebisch jest uważany za ojca strukturalistycznej teorii rozwoju gospodarczego, którego teoria dotarła do rozwijającego się świata, postrzegając Amerykę Łacińską jako coś odrębnego.

Koncepcja systemu centro-peryferyjnego Prebischa wynikała z faktu tego, że stosunki gospodarcze między krajami rozwiniętymi, traktowanymi jako centra światowej gospodarki kapitalistycznej, a krajami słabo rozwiniętymi, traktowanymi jako peryferia, charakteryzowały się nierówną wymianą, 
higher incomes and demand, while peripheral countries specialize in agricultural products with lower incomes and demand. This favored those countries with higher incomes per capita, while at the same time creating greater obstacles to the importation by the peripheral countries of the capital goods necessary for their development.

The starting point of Prebisch's analysis emerged as a critique of David Ricardo's theory of comparative advantage, which argued that countries should specialize in the production of products for which comparative cost advantages were present. The classic example of the application of this theory is the lower cost of labor for wine and textile production in Portugal than in England, with a comparative advantage in wine production rather than in tissue production (Souza 1993). Therefore, it would be more advantageous for both countries to produce wines in Portugal and textiles in England. From this theory, Latin America should produce food and raw materials for export and import manufactured goods. Thus, the peripheral countries would not need to industrialize to achieve development, since exchange relations would improve in view of the lower incorporation of technology in the primary sector and higher demand of the central countries, in view of the increase in income, resulting in an increase in the price of primary products.

The term "peripheral", used by Prebisch even before he joined ECLAC, meant Latin American vulnerability to economic cycles, resulting in inflationary processes with a strong exogenous component and tendencies toward internal cyclical contractions that, politically, potentiated unacceptable macroeconomic solutions (Bielsthowsky 2000).

The content of the cepaline analysis was based on studying and obtaining proper paths for the development of the Region, with the industrialization of the region as the main means of departing from the dependence of the central countries, since the relations of exchanges were unequal between these countries (Pinheiro, Souza, 2017).

Prebisch's strategy for the development of Latin America was based on the following points: (I) Compression of superfluous consumption, mainly of imported products, through high tariffs and restrictions on imported quantities; (II) Incentive to the inflow of foreign capital, in the form of government-to-government loans, seeking to increase investments for the implementation of basic infrastructure; (III) Agrarian reform to increase the supply of food and agricultural raw materials, as well as the demand for industrial products, through the expansion of the domestic market; (IV) Greater participation of the State in the collection of resources and in the implementation of infrastructures, such as energy, transportation, communications, among others.

This strategy was criticized, including those opposed to the industrialization of the periphery, as national groups linked to the agrarian-export oligarchy. However, at the end of the 1940s, Latin wyższą specjalizacją produkcji towarowej w krajach rozwiniętych jak również ich wyższymi dochodami i popytem, podczas gdy kraje peryferyjne specjalizują się w produktach rolnych i mają niższe dochody i popyt. Takie uwarunkowania sprzyjały krajom o wyższych dochodach na mieszkańca, a jednocześnie stwarzały większe przeszkody krajom peryferyjnym w imporcie dóbr kapitałowych niezbędnych do ich rozwoju.

Punktem wyjścia analizy Prebischa stała się krytyka teorii przewagi komparatywnej Davida Ricardo, która głosiła, że kraje powinny specjalizować się w wytwarzaniu produktów, które dawały komparatywną przewagę w kosztach. Klasycznym przykładem zastosowania tej teorii jest niższy koszt pracy przy produkcji wina i wyrobów włókienniczych w Portugalii niż w Anglii, z komparatywną przewagą raczej w produkcji wina niż w produkcji tekstyliów (Souza 1993). W związku z tym dla obu krajów korzystniejsze byłoby wytwarzanie win w Portugalii a wyrobów włókienniczych w Anglii. Zgodnie z tą teorią Ameryka Łacińska powinna produkować żywność i surowce na eksport a importować wyroby przemysłowe. W ten sposób kraje peryferyjne nie musiałyby przeprowadzać uprzemysłowienia, aby osiągnąć rozwój, ponieważ stosunki wymiany uległyby poprawie w związku z niższym wkładem technologii do sektora pierwotnego i wyższym popytem krajów centralnych, z uwagi na wzrost dochodów, skutkujących wzrostem cen produktów podstawowych.

Termin „peryferyjny”, używany przez Prebischa jeszcze przed wstąpieniem do ECLAC, oznaczał wrażliwość Ameryki Łacińskiej na cykle gospodarcze, co skutkowało procesami inflacyjnymi o silnym komponencie egzogennym i tendencjami do wewnętrznych cyklicznych spadków, które politycznie potęgowały niedopuszczalne rozwiązania makroekonomiczne (Bielsthowsky 2000).

Analiza opierała się na badaniu i wyznaczaniu właściwych dróg rozwoju dla regionu, z uprzemysłowieniem regionu jako głównym środkiem wyswobodzenia się z zależności od krajów centralnych, ponieważ bilans wymiany między tymi krajami były nierówny (Pinheiro, Souza 2017).

Strategia Prebischa dotycząca rozwoju Ameryki Łacińskiej opierała się na następujących punktach: (I) Ograniczenie zbędnej konsumpcji, głównie produktów importowanych, poprzez wysokie cła i ograniczenia kwot importowych; (II) Zachęcanie do napływu kapitału zagranicznego, w formie pożyczek międzyrządowych, zmierzających do zwiększenia inwestycji na rzecz budowy podstawowej infrastruktury; (III) Reforma rolna w celu zwiększenia dostaw żywności i surowców rolnych, jak również popytu na produkty przemysłowe, poprzez poszerzenie rynku krajowym; (IV) Większy udział państwa w gromadzeniu zasobów i budowie infrastruktury, między innymi w dziedzinie energii, transportu i łączności.

Strategia ta była krytykowana, włączając w to przeciwników uprzemysłowienia krajów peryferyjnych, w formie krajowych grup mających powiązania z agrarno-eksportową oligarchią. Niemniej pod koniec lat czterdziestych problemy gospodarcze Ameryki 
American economic problems worsened, confirming Prebisch's arguments regarding the deterioration of the terms of trade. Thus, it can be observed that the conception of the center-periphery system, the origin and basis of ECLAC's thinking, has a structuralist character.

In addition to the historical-structuralist approach, based on the idea of a relation between center-periphery, one can perceive the concern with the international insertion, the analysis of internal structural constraints and the necessity and possibilities of state action (Bielsthowsky 2000). Authors like Celso Furtado, Osvaldo Sunkel and others, articulated around ECLAC, gave continuity to Prebisch's ideas. The invisible hand of the market, for Prebisch, instead of correcting distortions, accentuated them, because the central countries appropriated most of the technical progress.

Also, it is possible to identify phases in the intellectual production of ECLAC, according to the message or "ideas-force", from the 50 's, at the height of the creativity of daring and influencing. At that point, ECLAC's ideology was embedded in the political projects of several Latin American governments, and there was harmony around the new development theory in which the underdeveloped countries deserved an independent or at least adapted theoretical formulation, different from those developed (Bielsthowsky 2000).

At the time, underdevelopment was not a process by which economies that had achieved a higher degree of development had passed, but an autonomous historical process (Furtado 1961). The industrialization proposed by Prebisch should occur through the substitution of imports, basing his vision on the need to increase productivity and accumulate capital to raise the well-being of the population (Cardoso 1993).

Already by the 1960 s, the idea was to redistribute to grow, the easy step of import substitution, based on the export of traditional products, was depleted. Substitutions were made with high costs and unfavorable capital / labor, usually in response to the demand for industrialized products, compared to primary products. In such a scenario, there was an incentive to export manufactured products, since the financing of imports of technology products increasingly demanded an increase in exports of non-traditional products, mainly industrialized products (Souza 1993).

In this period, in the face of a growing political-ideological polarization between East and West, three events in Latin American history radically affected ECLAC's thinking: (I) increasing macroeconomic instability and marked inflationary pressure; (II) the urbanization that happened with increased impoverishment, slumalization and growing dissatisfaction, translated into social pressures from the political and trade union milieus; (III) the Cuban Revolution of 1959, provoking changes in the American attitude, as a reaction to the political movement that spread throughout Latin America.
Łacińskiej zaostrzyły się, potwierdzając argumenty Prebischa dotyczące pogorszenia warunków handlu. Można zatem dostrzec, że koncepcja układu centro-peryferyjnego, geneza i podstawa linii myślenia ECLAC, ma charakter strukturalistyczny.

Oprócz podejścia historyczno-strukturalistycznego, opartego na idei relacji między centrum a peryferiami, można dostrzec troskę o włączenie międzynarodowe, analizę wewnętrznych ograniczeń strukturalnych oraz konieczność i możliwości działań ze strony państwa (Bielsthowsky 2000). Autorzy tacy jak Celso Furtado, Osvaldo Sunkel i inni, bazujący na ECLAC, zachowali ciągłość idei Prebischa. Niewidzialna ręka rynku, według Prebischa, zamiast korygować zniekształcenia, zaostrzała je, ponieważ kraje centralne przywłaszczyły sobie większość postępu technicznego.

W sferze intelektualnych wytworów ECLAC można wyróżnić pewne fazy, zgodnie z przesłaniem „idee-siła”, z lat 50-tych, w szczytowym momencie twórczego potencjału, wpływów i wyzwań. Wówczas ideologia ECLAC była osadzona w projektach politycznych kilku latynoamerykańskich rządów i nastała harmonia wokół nowej teorii rozwoju, w której kraje słabo rozwinięte zasługiwały na niezależne lub przynajmniej zaadaptowane sformułowanie teoretyczne, odmienne od tych już opracowanych (Bielsthowsky 2000).

W tym czasie niski stopień rozwoju nie był procesem, przez który przeszły gospodarki, które osiągnęły wyższy stopień rozwoju, ale autonomicznym procesem historycznym (Furtado 1961). Uprzemysłowienie proponowane przez Prebischa powinno zaistnieć poprzez substytucję importu. Jego wizja opierała się na potrzebie podniesienia wydajności i akumulacji kapitału w celu zwiększenia dobrobytu ludności (Cardoso 1993).

Już w latach sześćdziesiątych XX wieku sposób widziano w redystrybucji dla osiągnięcia wzrostu, natomiast uproszczony etap substytucji importu, oparty na eksporcie tradycyjnych produktów, został zredukowany. Substytuty wytwarzano przy wysokich kosztach oraz niekorzystnych warunkach kapitału i siły roboczej, zwykle w odpowiedzi na popyt na produkty przemysłowe, $\mathrm{w}$ porównaniu do produktów pierwotnych. W takim scenariuszu, powstawał bodziec do eksportu wytwarzanych wyrobów, ponieważ finansowanie importu produktów technologicznych w coraz większym stopniu wymagało zwiększenia eksportu produktów nietradycyjnych, głównie produktów przemysłowych (Souza 1993).

W tym okresie, w obliczu rosnącej polityczno-ideologicznej polaryzacji między Wschodem a Zachodem, trzy wydarzenia w historii Ameryki Łacińskiej radykalnie wpłynęły na linię myślenia ECLAC: (I) rosnąca niestabilność makroekonomiczna i znacząca presja inflacyjna; (II) urbanizacja, która pojawiła się wraz ze wzrostem zubożenia, populacji slumsów oraz stale rosnącego niezadowolenia, co przekładało się na społeczne naciski ze strony środowisk politycznych i związków zawodowych; (III) rewolucja kubańska z 1959 r., inspirująca zmiany w postawie społeczeństwa Ameryki, będące reakcją na ruch polityczny, który rozprzestrzenił się w Ameryce Łacińskiej. 
At that time, the United States abandoned the distrust of the McCarthy period (a period of intense anti-communist patrol, political persecution and disrespect for civil rights in the United States that lasted from the late 1940s to the mid-1950s) and implemented the Alliance Program for o Progress, conducted by the Organization of American States (OAS); of a "social democratic" position - Letter from Punta del Este - OAS, 1961, signed by the USA and most of the countries - with the purpose of neutralizing the possible spread of socialist ideals in Latin America. Since the Cuban regime emerged as an alternative of interest to the economies exploited over the centuries, in the capitalist mode of production (Lopes 2015). This new framework has led ECLAC to incorporate a discourse of a sociological nature, maintaining a dialogue with more moderate political positions.

ECLAC's diagnosis advocated political agendas for reforms within capitalism, in order to change the pattern and style of development through better distribution of income and profound reforms, agrarian, patrimonial, financial, tax, educational and technological, for needed profound political transformation, especially the recovery of democracy. While the Left presented the Revolution as the only way out, ECLAC redefined its conceptual framework to defend fairer "styles" of growth, proposing the central theme of the next decade (Bielsthowsky 2000). Additionally, in the 1970s, the thinking originated by ECLAC turned to the reorientation of development styles towards social homogenization and pro-export industrialization. From the mid-1960s until the oil shock in 1973 - the end of the global economic boom - Latin America generally experienced accelerated growth with an annual average of $6.7 \%$, with excellent export performance. There was excellent international liquidity, generating additional foreign exchange earnings to support the industrialization process. In Brazil, it was the so-called "economic miracle" period.

With the oil crisis and in the face of the recession, Latin America became even more indebted. This internal indebtedness was not the same in all countries. Brazil and Mexico have continued their industrialization process, with strong state participation. Argentina, Uruguay and Chile have completely opened up their foreign trade and their finances. This international crisis has brought to ECLAC's thinking a greater focus on macroeconomic analyzes, the issue of indebtedness and the necessary requirements for the diversification of exports. In general, there was a reduction in the influence of ECLAC on Latin American economic thinking, motivated by two events: the emergence in many countries of academic centers of excellence resulting from educational improvement and strengthening of state structures; and by the military coup that overthrew the Government of Salvador Allende in Chile, making the ECLAC headquarters in Santiago, from 1973, without the participation of the Latin American intelligentsia. This phase of ECLAC is
W tym czasie, Stany Zjednoczone porzuciły nieufność z okresu McCarthy'ego (okres intensywnych antykomunistycznych czystek, prześladowań politycznych oraz braku szacunku dla praw obywatelskich w Stanach Zjednoczonych, który trwał od późnych lat 40-tych do połowy lat pięćdziesiątych) i wdrożyły Program Sojuszu dla Postępu, prowadzony przez Organizację Państw Amerykańskich (OPA); stanowiska „socjaldemokratycznego" - list z Punta del Este - OPA, 1961, podpisany przez USA i większość krajów - w celu zneutralizowania możliwego rozprzestrzeniania się socjalistycznych ideałów w Ameryce Łacińskiej. Od chwili powstania reżim kubański jawił się jako interesująca alternatywa dla gospodarek wyzyskiwanych przez stulecia w kapitalistycznym sposobie produkcji (Lopes 2015). Ta nowa struktura skłoniła ECLAC do włączenia dyskursu o charakterze socjologicznym, utrzymując dialog z bardziej umiarkowanymi stanowiskami politycznymi.

Diagnoza ECLAC opowiadała się za politycznymi programami reform w kapitalizmie, w celu zmiany wzorca i stylu rozwoju poprzez lepszy podział dochodów oraz głębokie reformy agrarne, własnościowe, finansowe, podatkowe, edukacyjne i technologiczne, dla potrzebnej głębokiej reformy politycznej, zwłaszcza dla uzdrowienia demokracji. Podczas gdy Lewica przedstawiała Rewolucję jako jedyną drogę wyjścia, ECLAC na nowo zdefiniowała swoje ramy koncepcyjne i zaproponowała wiodący temat na następną dekadę w celu obrony bardziej sprawiedliwych "stylów" rozwoju (Bielsthowsky 2000). Ponadto, w latach 70 sposób myślenia zainicjowany przez ECLAC zwrócił się w stronę reorientacji modeli rozwojowych w kierunku jednorodności społecznej oraz uprzemysłowienia proeksportowego. Od połowy lat 60-tych do szoku naftowego w 1973 roku - końca globalnego boomu gospodarczego - Ameryka Łacińska na ogół odnotowała przyspieszony wzrost z roczną średnią wynoszącą 6,7\%, z doskonałymi wynikami eksportowymi. Występowała bardzo korzystna międzynarodowa wymiana towarowa, generująca dodatkowe dochody $\mathrm{z}$ wymiany walutowej w celu wsparcia procesu uprzemysłowienia. W Brazylii, był to tak zwany okres „cudu gospodarczego".

Wraz z kryzysem naftowym i w obliczu recesji, Ameryka Łacińska stała się jeszcze bardziej zadłużona. Nie we wszystkich krajach wewnętrzne zadłużenie było takie samo. Brazylia i Meksyk kontynuowały proces uprzemysłowienia, z silnym udziałem państwa. Argentyna, Urugwaj i Chile całkowicie otworzyły własny handel zagraniczny oraz swoje finanse. Ten międzynarodowy kryzys sprawił, że ECLAC skupiła się głownie na analizach makroekonomicznych, kwestiach zadłużenia oraz na potrzebach w zakresie dywersyfikacji eksportu. Ogólnie rzecz biorąc, nastąpił spadek wpływu ECLAC na latynoamerykańską myśl ekonomiczną, do czego przyczyniły się dwa wydarzenia: pojawienie się akademickich ośrodków doskonalenia w wielu krajach, które były pochodną poprawy edukacji oraz wzmocnienia struktur państwowych; wojskowy zamach stanu, który obalił rząd Salvadora Allende w Chile, odcinający od 1973 główną siedzibę ECLAC w Santiago od udziału inteligencji latynoame- 
classified as "survival". Even so, the concern for development in the medium and long term remained safe.

With the crisis, in the 1980s, there remained the attempt to overcome the problem of external indebtedness, with adjustment and stabilization policies. Caused by the indebtedness and recession that followed the oil shock in 1973, put an end to development projects. Several currency declines, higher US interest rates, and lower capital inflows have led to recession in most economies. From then on, ECLAC's intellectual effort was in opposition to the kinds of adjustments required by creditor banks and the International Monetary Fund (IMF), with preference for immediate debt, stabilization, and adjustment issues.

After this period of "survival", there is the return of ECLAC's most important debate: the process of economic growth in the long term, with the document "Productive Transformation with Equity", published in 1990. It maintains a good number of elements of the initial thinking of Prebisch and reconsiders the growth strategy, recognizing deficiencies in the model of industrialization of the past, the lack of acceptance of technical progress, and often being blocked by the business classes.

The objective of this opening is to avoid technological isolation in the era of productive globalization, electronic revolution and biotechnology, with the acceleration of technological learning, as a strategy of expansion and increase of export coefficients. The new ECLAC structure recovers the agenda of analyzes and development policies with adaptation to the new times of openness and globalization. Latin America also needs a set of public policies that support development in the light of regional peculiarities (Bielsthowsky 2000). At this point, the theory of dependency, presented below, is inserted.

\section{The dependency theory}

The theory of dependence has been called the set of theories and models that are intended to explain the difficulties that some countries face in reaching economic development. These theories developed in the sixties, through economists like Prebisch and under the context of ECLAC Initially, these theories addressed the Latin American reality and were later generalized by neo-Marxist economists, of whom Samir Amin, who associated with the concept of unequal and combined development, stands out.

The theory of dependence originated along with the structuralist theories of Latin American scholars, extending to other theories, both from the scope of economics, and from sociology, representing a reflection on the paradigm of the economic development of capitalism of the fifties and its consequences of the underdevelopment of the so-called developing countries and their difficulties facing the world economy (Oliveira 2000). The proposal of Prebisch and ECLAC was the basis of rykańskiej. Ta faza ECLAC jest klasyfikowana jako „przetrwanie”. Mimo to, troska o rozwój w perspektywie średnio i długoterminowej przetrwała.

Wraz z kryzysem w latach 80 kontynuowano próby przezwyciężenia problemu zewnętrznego zadłużenia poprzez politykę dostosowawczą i stabilizacyjną. Kryzys ten spowodowany został przez zadłużenie i recesję, które nastąpiły po szoku naftowym w 1973 r., i położył kres projektom rozwojowym. Szereg spadków kursów walut, wyższe stopy procentowe w USA oraz niższy napływ kapitału doprowadziły do recesji w większości gospodarek. Od tego momentu, wysiłki intelektualne ECLAC były w opozycji do strategii dostosowawczych wymaganych przez banki wierzycieli oraz przez Międzynarodowy Fundusz Walutowy (MFW), preferując natychmiastowe zadłużenie, stabilizację oraz problemy dostosowawcze.

Po tym okresie „przetrwania”, następuje powrót najważniejszego punktu debaty ECLAC: proces długoterminowego wzrostu gospodarczego, wraz z dokumentem „Transformacja produktywna z kapitałem własnym”, opublikowanym w 1990 roku. Utrzymuje on znaczną liczbę elementów z początkowego stylu myślenia Prebischa oraz ponownie rozważa strategię rozwoju, dostrzegając braki w modelu uprzemysłowienia w przeszłości, brak akceptacji dla postępu technicznego oraz częste blokowanie przez klasę przedsiębiorców.

Celem tego otwarcia jest uniknięcie izolacji technologicznej w erze produktywnej globalizacji, rewolucji elektronicznej oraz biotechnologii, wraz z przyspieszeniem procesu przyswajania technologii, jako strategii ekspansji i wzrostu współczynników eksportu. Nowa struktura ECLAC odnawia program analiz i programów polityki rozwojowej dostosowując się do nowych czasów otwartości i globalizacji. Także Ameryka Łacińska potrzebuje zestawu programów politycznych wspierających rozwój w świetle wiedzy o specyfice regionalnej (Bielsthowsky 2000). Poniżej przedstawiono teorię zależności.

\section{Teoria zależności}

Teoria zależności jest nazwą nadaną zbiorowi teorii i modeli, które mają wyjaśnić trudności, z którymi niektóre kraje mają do czynienia w trakcie osiągania rozwoju gospodarczym. Teorie opracowane w latach sześćdziesiątych, dzięki ekonomistom takim jak Prebisch, początkowo w kontekście ECLAC, odnosiły się do rzeczywistości latynoamerykańskiej i zostały później uogólnione przez neomarksistowskich ekonomistów, z których wyróżnia się Samir Amin, kojarzący się z koncepcją rozwoju nierównego i łączonego.

Teoria zależności powstała wraz z teoriami strukturalnymi uczonych latynoamerykańskich, rozciągając się na inne teorie, zarówno z zakresu ekonomii, jak i socjologii, przedstawiając refleksję nad paradygmatem rozwoju gospodarczego kapitalizmu lat pięćdziesiątych i jego konsekwencjami dla słabego rozwoju tzw. krajów rozwijających się i ich trudności w obliczu gospodarki światowej (Oliveira 2000). Propozycja Prebischa i ECLAC stała się podstawą teorii zależności. Wśród głównych autorów tej teorii są: André Gunder 
dependency theory. Among the main authors of this theory are André Gunder Frank, Raúl Prebisch, Theotonio dos Santos, Fernando Henrique Cardoso, Edelberto Torres-Rivas and Samir Amin.

Economic dependence is a situation in which the production and wealth of some countries is conditioned by the development and the economic conditions of other countries to which they are subject. The "center-periphery" model describes the relationship between the central, self-sufficient and prosperous economy and peripheral economies, which arealien to each other, weakand uncompetitive, and the classic idea that international trade benefits all those involved only the core economies.

Underdevelopment is not a consequence of archaic institutions, lack of capital in regions that have remained far from the normal course of history, but rather, underdevelopment has been and is generated by the same historical process that also generates the economic development of own capitalism (Frank 1969). As the author points out, the mechanisms by which international trade aggravates poverty in peripheral countries are diverse:

a. International specialization gives the peripheral countries the role of exporting producers of raw materials and agricultural products and consumers and importers of industrial and technologically advanced products;

b. The monopolization of the central economies allows technological development to result in wage increases and prices, while in the periphery they translate into price reductions;

c. Economic expansion has different effects on the demand for industrial products and on agricultural production. When peripheral countries grow economically, their imports tend to increase faster than their exports. Consequently, the Latin American countries implement a development strategy based on trade protectionism and the substitution of exports. Central banks are struggling to overvalue their own currencies to cheapen imports of technology.

This strategy worked satisfactorily during the seventies, with a generalized increase in raw material prices in international markets, negatively influencing the central economies. Still, the contraction of international demand and the increase in the interest rate triggered in the $1980 \mathrm{~s}$ external debt crises, which necessitated changes in the development strategy.

Dependency theory combines neo-Marxist elements with Keynesian economic theory (based on liberal economic ideas that have emerged in the US and Europe as a response to the depression of the 1920s). Based on Keynes' economic approach, dependency theory is composed of four fundamental points: a) to develop a considerable effective domestic demand in terms of national markets; b) recognize that the sector industry is important for achieving better levels of national development, especially as this sector generates greater added value to products
Frank, Raúl Prebisch, Theotonio dos Santos, Fernando Henrique Cardoso, Edelberto Torres-Rivas oraz Samir Amin.

Zależność ekonomiczna to sytuacja, w której produkcja i bogactwo niektórych krajów są uwarunkowane rozwojem i warunkami gospodarczymi innych krajów, którym podlegają. Model „centro-peryferyjny” opisuje związek między centralną, samowystarczalną i dobrze prosperującą gospodarką a gospodarkami peryferyjnymi, które są słabe i niekonkurencyjne oraz wzajemnie sobie obce, jak również i klasyczną koncepcję, według której międzynarodowy handel przynosi korzyści tylko tym którzy są związani z kluczowymi gospodarkami.

Słaby rozwój gospodarczy jest nie tyle konsekwencją przestarzałych instytucji czy też braku kapitału $\mathrm{w}$ regionach, które pozostały $\mathrm{z}$ dala od normalnego biegu historii, co raczej spowodowane on został, i wciąż jest, przez ten sam proces historyczny, który odpowiada również za rozwój ekonomiczny własnego kapitalizmu (Frank 1969). Zdaniem autora, mechanizmy, za pomocą których handel międzynarodowy pogarsza ubóstwo w krajach peryferyjnych, są zróżnicowane:

a. Międzynarodowa specjalizacja obsadza kraje peryferyjne w roli producentów eksportujących surowce i produkty rolne, a także w roli konsumentów i importerów produktów przemysłowych i technologicznie zaawansowanych;

b. Monopolizacja gospodarek centralnych sprawia, że rozwój technologiczny skutkuje wzrostem płac i cen, podczas gdy na peryferiach przekłada się ona na obniżki cen;

c. Ekspansja gospodarcza ma odmienny wpływ na popyt na produkty przemysłowe i na produkcję rolną. Gdy kraje peryferyjne rozwijają się gospodarczo, ich import ma tendencję do szybszego wzrostu niż eksport. W związku z tym kraje latynoamerykańskie wdrażają strategię rozwoju oparta na protekcjonizmie handlu i substytucji eksportu. Banki centralne starają się przeceniać własne waluty w celu wpłynięcia na potanienie importu technologii.

Strategia ta działała zadowalająco w latach siedemdziesiątych, przy ogólnym wzroście cen surowców na rynkach międzynarodowych, który negatywnie wpływał na gospodarki centralne. Jednakże kurczenie się międzynarodowego popytu i wzrost stopy procentowej doprowadziły w latach osiemdziesiątych do kryzysu zadłużenia zewnętrznego, co wymagało zmian w strategii rozwoju.

Teoria zależności łączy w sobie elementy neomarksistowskie z Keynesowską teorią ekonomiczną (opartą na liberalnych ideach gospodarczych, które pojawiły się w USA i Europie jako odpowiedź na wielką depresję w latach dwudziestych). Opierając się na podejściu ekonomicznym Keynesa, teoria zależności składa się z czterech podstawowych punktów: a) wytworzenia znacznego efektywnego popytu lokalnego na rynkach krajowych; b) uznanie, że przemysł branżowy jest ważny dla osiągnięcia wyższego poziomu rozwoju krajowego, zwłaszcza że sektor ten generuje większą wartość dodaną w stosunku do produktów z sektora 
compared to the agricultural sector; c) increase as a means of generating aggregate demand and national market conditions; d) to promote a more effective governmental role to reinforce the conditions of national development and raise the standards of life of the country (Santos 1971).

According to the school of dependency, the main developmental hypotheses in Third World countries are: a) the development of these countries needs to have a degree of subordination to the center in contrast to the development of the central nations whose development has been historically and in independent day; b) dependentistas in general consider that the peripheral nations experience greater economic development when their relations with the center are more weakened, so, for example, it is the reality of years 30 to 40 , when the nations of the center were centered in the solution of the problems the Great Depression and the western powers involved in the Second World War; c) when the countries of the center recover their crisis and reestablish their commercial and financial ties, they incorporate the peripheral countries back into the system and their growth and industrialization tends to be subordinated (Frank 1969).

The dependence of underdeveloped countries results more from technological industrial production than from financial ties to monopolies of the central countries (Santos, 1971). Thus, dependency theory is the complement to the theory of imperialism as it relates to the functioning of the capitalist system in underdeveloped countries (Santos 2000). Dependent doctrine meant an alternative milestone for the development of Latin American countries and a new vision between center-periphery. Development strategies for the time being, emphasizing industrialization through import substitution, state planning and interventionism, regionalization, and integration have all produced positive results in favor of the development of peripheral countries (Hetne 1982).

ECLAC strategies worked for a short period and later experiences showed that import substitution was, if not wrong, inadequate, since the industrial process needed inputs, which had to be imported and created technological and financial dependence; the distribution pattern confined the demand for manufactures to a relatively minority elite, inhibiting growth (Hetne 1982).

One of the main criticisms is made of dependency and modernization theory, since both are still based on the perspective of nation-states. Globalization and the role of new actors in international society introduce other links that influence development, and a new paradigm for the international relations (of interdependence). These new links can be decisive in the transfer of technology, and as an example, the US is a colony of countries that have been able to break the vicious circle of development.

In this context, the evolution of the socioeconomic situation of Latin America, from the 1960s to the present, is triggered by a process of dependence on the developed countries and their mistaken pre- rolnego; c) wzrost jako środek generowania łącznego popytu i warunków rynku krajowego; d) promowanie skuteczniejszej roli rządu w poprawie warunków rozwoju krajowego i podniesieniu standardów życia w kraju (Santos 1971).

Zgodnie ze szkołą zależności, główne hipotezy rozwojowe w krajach Trzeciego Świata to: a) rozwój tych krajów musi być w pewnym stopniu podporządkowany centrum, w przeciwieństwie do rozwoju narodów centralnych, których rozwój był historycznie samodzielny; b) wyznawcy teorii zależności ogólnie uważają, że narody peryferyjne doświadczają większego rozwoju gospodarczego, gdy ich relacje z centrum są w większym stopniu osłabione, a więc na przykład $\mathrm{w}$ realiach lat trzydziestych i czterdziestych, kiedy narody centrum koncentrowały się na rozwiązaniu problemów Wielkiego Kryzysu a mocarstwa zachodnie angażowały się w II Wojnę Światową; c) kiedy kraje centrum ustabilizują swoją sytuację kryzysową i przywrócą swoje więzi handlowe i finansowe, włączają one kraje peryferyjne z powrotem do systemu, a ich rozwój i uprzemysłowienie ma tendencję do ulegania podporzadkowaniu (Frank 1969).

Zależność krajów słabo rozwiniętych wynika bardziej z technologicznej produkcji przemysłowej niż $\mathrm{z}$ więzi finansowych z monopolami krajów centralnych (Santos 1971). Tak więc teoria zależności jest uzupełnieniem teorii imperializmu, ponieważ odnosi się do funkcjonowania systemu kapitalistycznego w krajach słabo rozwiniętych (Santos 2000). Doktryna zależności stanowiła kamień milowy dla rozwoju krajów Ameryki Łacińskiej i nową wizję w relacjach między centrum i peryferiami. Na chwilę obecną, strategie rozwoju skupiające się na uprzemysłowieniu poprzez substytucję importu, planowaniu państwowym i interwencjonizmie, a także regionalizacji i integracji, przyniosły pozytywne rezultaty w kwestii rozwoju krajów peryferyjnych (Hetne 1982).

Strategie ECLAC działały przez krótki okres, a późniejsze doświadczenia pokazały, że substytucja importu była może nie tyle zła co nieadekwatna, gdyż proces przemysłowy wymagał nakładów, które musiały zostać zaimportowane, co spowodowało zależność technologiczną i finansową; schemat dystrybucji ograniczył popyt na wyroby do względnie mniejszościowych elit, hamując tym samym wzrost (Hetne 1982).

Jedna z głównych linii krytyki wynika z teorii zależności i modernizacji, ponieważ obie są wciąż oparte na perspektywie państw narodowych. Globalizacja i rola nowych podmiotów w społeczeństwie międzynarodowym wprowadzają inne powiązania, które wpływają na rozwój oraz tworzą nowy paradygmat stosunków międzynarodowych (współzależności). Te nowe powiązania mogą mieć decydujący wpływ na transfer technologii. Na przykład Stany Zjednoczone są kolonią krajów, które były w stanie przełamać błędne koło rozwoju.

W tym kontekście ewolucja sytuacji społeczno-ekonomicznej Ameryki Łacińskiej od lat sześćdziesiątych do chwili obecnej jest wynikiem procesu zależności od krajów rozwiniętych i ich nieodpowiednich warunków przedkapitalistycznych. Tak więc, ECLAC zdecy- 
capitalist condition. Thus, ECLAC went so far as to deal with issues such as exchange relations and industrialization (Santos 1971).

The paradigmatic work of economic dependence was produced in $1966 / 67$ by Enzo Faletto and Fernando Henrique Cardoso, and sought to highlight the social and political nature of the process, in historical moments and different structural situations. This thought found its basis in the reflections of Raúl Prebisch, with ECLAC (Oliveira 2000). The theory of dependence can also be worked through purely scientific criteria, moving away from the ideological point of view, and can be done through the analysis of three orders:

a. Theoretical status of the concept of dependency: through the analysis that dependent structures have their own evolution, within the limits defined by the relations of domination-subordination between countries;

b. Relation between dependent structure and dominant structure: that occurs through the world market;

c. Relationship between development theory and dependency theory (Cardoso, Faletto 1970).

From this exposition, it is inferred that the relation between the so-called developed and underdeveloped societies begins with the development of capitalism as a world system of production. In this process, the economic, social and political functions are also defined through the world market and are a macrosystem in which two types of society are found, with different destinies: in the center, the metropolises are located, surrounded by peripheral societies, satelitized, undeveloped, which is in a situation of dependence and exploitation in relation to central and developed societies.

The situation of underdevelopment occurred historically when the expansion of commercial capitalism and after industrial capitalism linked to the same market economies that, besides presenting varying degrees of differentiation of the productive system, came to occupy different positions in the global structure of the capitalist system. (...) Thus, between developed and underdeveloped economies, there is not a simple difference of stage or stage of the productive system, but also of function or position within the same international economic structure of production and distribution. This supposes, on the other hand, a definite structure of relation of domination. However, the concept of underdevelopment, as it is usually employed, refers more to the structure of a type of economic system, with a predominance of the primary sector, a strong concentration of income, a little differentiation of the productive system and, above all, a predominance of the external market on the internal. This is manifestly insufficient (Cardoso, Faletto 1970).

The question of the dependence of the peripheral countries, explained on the one hand by the structuralist theory and on the other by the Marxist theory, points to a pessimism regarding the possibility of harmonious coexistence between the states and balanced development, since the dowała się zająć takimi kwestiami, jak teoria wymiany i industrializacja (Santos 1971).

Sztandarowa praca na temat zależności ekonomicznej została przedstawiona w latach 1966/67 przez Enzo Faletto i Fernando Henrique Cardoso i miała na celu uwypuklenie społecznej i politycznej natury procesu, w momentach historycznych i różnych uwarunkowaniach strukturalnych. Ta myśl znalazła swoje odzwierciedlenie w refleksjach Raúla Prebischa z ECLAC (Oliveira 2000). Teorię zależności można również przeanalizować przy pomocy czysto naukowych kryteriów, odchodzac od ideologicznego punktu widzenia, i można to zrobić poprzez analizę trzech porządków:

a. Teoretyczny status pojęcia zależności: analizując, że struktury zależne mają własną ewolucję w granicach określonych przez relacje dominacji-podporządkowania pomiędzy krajami;

b. Relacja między strukturą zależna a struktura dominującą: występująca na rynku światowym;

c. Związek między teorią rozwoju a teorią zależności (Cardoso, Faletto 1970).

$\mathrm{Z}$ tego wywodu wynika, że związek między tak zwanymi rozwiniętymi i słabo rozwinietymi społeczeństwami zaczyna się od rozwoju kapitalizmu jako światowego systemu produkcji. W procesie tym funkcje gospodarcze, społeczne i polityczne są również definiowane na rynku światowym i tworzą makrosystemem, w którym znajdują się dwa typy społeczeństwa o różnym przeznaczeniu: w centrum znajdują się metropolie, które sa otoczone przez słabo rozwinięte społeczeństwa peryferyjne, znajdujące się $\mathrm{w}$ położeniu zależności i eksploatacji w stosunku do społeczeństw centralnych i rozwiniętych.

Sytuacja zacofania gospodarczego występowała w historii, gdy ekspansja komercyjnego kapitalizmu i później kapitalizmu przemysłowego wiązała się z tymi samymi gospodarkami rynkowymi, które oprócz posiadania różnych stopni zróżnicowania systemu produkcyjnego, zajęły także różne pozycje w globalnej strukturze systemu kapitalistycznego. (...), Tak więc, pomiędzy rozwiniętymi i słabo rozwiniętymi gospodarkami nie ma zwyczajnej różnicy po względem stopnia lub etapu systemu produkcyjnego, ani także pod względem funkcji lub pozycji w ramach tej samej mieddzynarodowej struktury gospodarczej produkcji i dystrybucji. Z drugiej strony, zakłada to określoną strukturę stosunku dominacji. Jednak koncepcja niskiego stopnia rozwoju, jak to zwykle bywa, odnosi się bardziej do struktury typu systemu gospodarczego, z przewagą sektora pierwotnego, silnej koncentracji dochodów, niewielkiego zróżnicowania systemu produkcyjnego, a przede wszystkim, do struktury z przewagą rynku zewnętrznego nad wewnętrznym. Jest to zdecydowanie niewystarczajace (Cardoso, Faletto, 1970).

Kwestia zależności krajów peryferyjnych, wyjaśniona $\mathrm{z}$ jednej strony przez teorię strukturalizmu, a $\mathrm{z}$ drugiej przez teorię marksistowską, wskazuje na pesymizm dotyczący możliwości harmonijnego współżycia państw i zrównoważonego rozwoju z powodu asymetrycznej i nierównej współpracy między krajami bogatymi i biednymi (Oliveira 2000). 
asymmetric and unequal cooperation between rich and poor countries (Oliveira 2000).

ECLAC, however, considered the nation-state as the main actor, despite the global character of the system. Nowadays, with the restrictions of the nation-states in their decision-making power, from the beginning of the seventies and the interaction of new actors with decision-making power in the context of international relations, ECLAC doctrine loses its force.

The current international economic system is characterized by the slow and intensive disappearance of the stability of the international monetary system, the decline in economic growth rates, the stagnation of productive investments and the rise of speculative accumulation, the increase of permanent unemployment rates, the tendency to invest preferentially in the replacement of machinery and equipment and in the rationalization of productive processes and not in the expansion of productive capacity. The incorporation of new technologies is added to the transformations in the social organization of work.

Even though it lost its strength in the early 1970s, ECLAC remained active at the turn of the century, remaining important on the world stage and its current work is presented below.

\section{ECLAC's current thinking}

Faced with the non-overcoming of underdevelopment, we have seen that the ECLAC debates are still current. Five elements that make up the ECLAC analysis that remains today are highlighted: the issue of international insertion and the external vulnerability of Latin American peripheral countries, which is currently aggravated by the financial fragility resulting from globalization; persistence of the weakness of institutional, productive and social structures that require corrective policies; difficulties in the creation, incorporation and diffusion of technical progress; search for the integration between technical progress, employment and income distribution; the structuralist analysis and reading of the inflationary process (Bielsthowsky 2000).

Thus dependency theory has also been reinvigorated by international economic crises and globalization, which is demonstrating that national economies are integrated and dependent on the world capitalist dynamics dictated by the major decision-making centers. As a consequence, ECLAC thought today, in a stance contrary to the Washington Consensus, lies in the current that, from Karl Polanyi to Amartya Sen, postulates the subordination of the economic system to social objectives. It sought to balance the market and the public interest, with the construction and reconstruction of institutions and the formulation of public policies aimed at correcting market and government failures (Sachs 2001).

For the same author, the issues of underdevelopment and dependence on rich countries do not represent the whole problem. "Another part
ECLAC uznała jednak państwo narodowe za główny podmiot, pomimo globalnego charakteru systemu. W obecnej dobie, wraz z ograniczeniami dla państw narodowych pod względem uprawnień decyzyjnych od początku lat siedemdziesiątych i wobec interakcji nowych podmiotów z władzami ferującymi decyzje w kontekście stosunków międzynarodowych, doktryna ECLAC traci swoją moc.

Obecny międzynarodowy system gospodarczy charakteryzuje się powolnym i intensywnym zanikaniem stabilności międzynarodowego systemu monetarnego, spadkiem tempa wzrostu gospodarczego, stagnacją inwestycji produkcyjnych i wzrostem akumulacji spekulacyjnej, wzrostem stałych stóp bezrobocia, tendencją do inwestowania z preferencjami do wymiany maszyn i urządzeń oraz $\mathrm{w}$ racjonalizację procesów produkcyjnych, a nie w zwiększanie zdolności produkcyjnych. Wdrażanie nowych technologii zwiększa ilość przemian w społecznej organizacji pracy.

Mimo że na początku lat 70 utraciła swój wpływ, ECLAC pozostała aktywna na przełomie stuleci, utrzymując swoje znaczenie na arenie światowej, a jej obecne działania przedstawiono poniżej.

\section{Obecny sposób myślenia ECLAC}

W obliczu sytuacji, w której niski stopień rozwoju nie został przezwyciężony, dostrzegamy to, że problemy podejmowane przez ECLAC są wciąż aktualne. Pięć elementów składających się na analizę ECLAC, która wciąż zachowuje swoją aktualność: kwestia międzynarodowego włączenia i zewnętrznej wrażliwości krajów peryferyjnych Ameryki Łacińskiej, która jest obecnie pogarszana przez niestabilność finansową wynikającą z globalizacji; utrzymywanie się słabości struktur instytucjonalnych, produkcyjnych i społecznych, które wymagają polityki naprawczej; trudności w tworzeniu, wdrażaniu i upowszechnianiu postępu technicznego; poszukiwanie integracji między postępem technicznym, zatrudnieniem i dystrybucją dochodów; analiza strukturalistyczna i reakcja na proces inflacyjny (Bielsthowsky 2000).

Tym samym teoria zależności została również wzmocniona przez międzynarodowe kryzysy gospodarcze i globalizację, co pokazuje, że gospodarki narodowe są zintegrowane i zależne od dynamiki światowego kapitalizmu, pozostającej pod dyktatem głównych ośrodków decyzyjnych. W konsekwencji, współczesne poglądy ECLAC, w przeciwieństwie do konsensusu waszyngtońskiego, znajdują się $\mathrm{w}$ nurcie, który, od Karla Polanyi do Amartya Sen, postuluje podporządkowanie systemu gospodarczego celom społecznym. Dążono w nim do zrównoważenia rynku i interesu publicznego, z budową i odbudową instytucji oraz formułowaniem programów polityki publicznej mających na celu naprawienie błędów rynkowych i rządowych (Sachs 2001).

Dla tego samego autora, problemy niskiego stopnia rozwoju i zależności od bogatych krajów nie określają 
of the problem is the lack of cooperation among developing countries (the group of 77). Instead of opting to take joint action, they compete with each other for foreign investment".

Faced with such a scenario, development should take place endogenously, through social cohesion and the accumulation of human capital and knowledge. Moreover, the international order needs, at the same time, to open a wide space to the work of networks of strong institutions, through a system of "open regionalism" (Ocampo 2001). The author argues that two main themes can not fail to be reflected in the debates on development: the new balance between the market and the public interest; and public policies. For him, markets can benefit from measures that help them function and ensure equitable distribution of development results; and public policies must be a form of state action exclusively state-owned around the common interest.

The development of rural development policies, the formalization of microenterprises and the gradual inclusion in the social security system are essential if there is to be a generalized and equitable development and that produces the right chains, democratization of access to productive assets and technological innovation. of the self-employed and the employees of the small enterprises (Sachs 2001). Therefore, dependence and development can occur together, as Cardoso (2003) states in a speech at ECLAC: "We have never seen a contradiction between development and dependence".

\section{Conclusion}

The study of the trajectory of ECLAC's thinking in these more than sixty-five years offers a reflection on the aspects related to the development of Latin America, demonstrating the long road ahead. What is important is that ECLAC's thinking comes from the perspective of peripheral countries and not from the traditional doctrines, from the point of view of the central countries.

Before stating that ECLAC or its thinking are overcome, it should be taken as a starting point for the ever deepening of the theme in the search for feasible solutions to our reality. The most important point is that development is again on the agenda of ECLAC, with the search for a new international order that opens spaces for the work of networks of strong regional institutions that can support endogenous processes. It may be necessary to begin to indicate the positive aspects of this trajectory and the regional potentialities, in order to find plausible and adequate solutions for the peculiar development of Latin America.

The resumption of development, through the application of the ideas of Ocampo and Sachs, with the system of "open regionalism", endogenous processes and the implementation of rural development policies, based on the particularities of each region, allows us to glimpse a more promising future for Latin America. całości problemu. „Kolejną częścią problemu jest brak współpracy między krajami rozwijającymi się (grupa 77). Zamiast decydować się na wspólne działania, konkurują ze sobą o inwestycje zagraniczne „.

W obliczu takiego scenariusza, rozwój powinien następować endogenicznie, poprzez spójność społeczną oraz akumulację kapitału ludzkiego i wiedzy. Co więcej, porządek międzynarodowy musi jednocześnie otworzyć szeroką przestrzeń dla działania sieci silnych instytucji, poprzez system „otwartego regionalizmu" (Ocampo 2001). Autor ten twierdzi, że dwa główne tematy nie mogą nie znaleźć odzwierciedlenia w debatach na temat rozwoju: nowa równowaga pomiędzy rynkiem a interesem publicznym oraz programy polityki publicznej. Według niego, rynki mogą czerpać korzyści ze środków, które pomagają im funkcjonować i zapewniają sprawiedliwą dystrybucję efektów rozwoju; a polityka publiczna musi być formą działania państwa wyłącznie w ramach wspólnego interesu.

Rozwój programów politycznych dla rozwoju obszarów wiejskich, formalizacja mikroprzedsiębiorstw i stopniowe włączanie do systemu zabezpieczenia społecznego są niezbędne, jeśli ma zaistnieć powszechny i sprawiedliwy rozwój, który zapewnia właściwe kanały dystrybucji, demokratyzację dostępu do środków produkcji i innowacji technologicznych osobom samozatrudnionym i pracownikom małych przedsiębiorstw (Sachs2001). Dlatego też zależność i rozwój mogą występować razem, jak twierdzi Cardoso (2003) w przemówieniu dla ECLAC: „Nigdy nie widzieliśmy sprzeczności między rozwojem a zależnością".

\section{Wnioski}

Badanie torów jakimi przebiegało myślenia ECLAC w przeciągu sześćdziesięciu pięciu lat jej istnienia skłania do refleksji nad aspektami związanymi z rozwojem Ameryki Łacińskiej i wskazuje na długa drogę, którą jeszcze trzeba przebyć. Ważne jest to, że poglądy ECLAC wywodzą się z perspektywy krajów peryferyjnych, a nie z tradycyjnych doktryn, $\mathrm{z}$ punktu widzenia krajów centralnych.

Zanim stwierdzimy, że ECLAC lub jego poglądy poniosły klęskę, należy to potraktować jako punkt wyjścia do nieustającego zgłębiania tematu w poszukiwaniu wykonalnych rozwiązań dla naszej rzeczy wistości. Najważniejszą kwestią jest to, że rozwój jest ponownie na porządku obrad ECLAC, wraz z poszukiwaniem nowego porządku międzynarodowego, który otwiera przestrzeń dla działania sieci silnych regionalnych instytucji, które mogą wspierać procesy endogenne. Koniecznym może się okazać wskazanie pozytywnych aspektów $\mathrm{w}$ tym torze myślenia i regionalnych potencjałów, aby znaleźć wiarygodne i odpowiednie rozwiązania dla szczególnej drogi rozwoju Ameryki Łacińskiej.

Wznowienie rozwoju, poprzez zastosowanie idei Ocampo i Sachs, z systemem „otwartego regionali$\mathrm{zmu}$ ", procesami endogenicznymi i wdrażaniem polityki rozwoju obszarów wiejskich, w oparciu o specyfikę każdego regionu, pozwala nam ujrzeć bardziej obiecującą przyszłość dla Ameryki Łacińskiej. 
Specifically, the subject set forth in this article encourages the rapprochement between Latin America and Europe and places the issue of development as the central theme again in order to seek solutions and make the regions of Latin America and Europe protagonists in discussing a more active policy to reduce inequalities by bringing new ideas to the debate that has already been initiated by ECLAC.
W szczególności temat przedstawiony $\mathrm{w}$ tym artykule zachęca do zbliżenia między Ameryką Łacińską a Europą i ponownie stawia kwestię rozwoju jako główny temat, aby znaleźć rozwiązania i sprawić, że regiony Ameryki Łacińskiej i Europy będą walczyć o bardziej aktywną politykę w celu zmniejszania nierówności poprzez wnoszenie nowych pomysłów do debaty zainicjowanej już przez ECLAC.

\section{References / Literatura:}

1. Bielsthowsky R. (2000), Cinquenta anos de pensamento na CEPAL. Record/ COFECON/CEPAL, São Paulo.

2. Cardoso F. H. (1993), As ideias e seu lugar. Vozes, Petrópolis.

3. Cardoso F. H. (2003), Más allá de la Economia: interación entre política y desarrollo económico. Santiago de Chile, CEPAL, Tercera Catedra Raúl Prebish.

4. Cardoso F. H., Faletto E. (1970), Dependência e Desenvolvimento na América Latina: Ensaio de Interpretação Sociológica. LTC, 7. ed. Rio de Janeiro.

5. Cervo A. R., Bervian P. A. (2002), Metodologia científica. 5. ed. Prentice Hall, São Paulo.

6. Frank A. G. (1969), América Latina: Subdesarrollo o Revolución. Editorial ERA, México.

7. Furtado C. (1961), Desenvolvimento e subdesenvolvimento. Fundo de Cultura, Rio de Janeiro.

8. Furtado C. (1974), O mito do desenvolvimento econômico. Paz e Terra, Rio de Janeiro.

9. Gil A. C. (2009), Métodos e técnicas de pesquisa social. 6. ed. Atlas, São Paulo.

10. Hetne B. (1982), Teorias Del Desarrollo y El Tercer Mundo. SADEC, Suécia.

11. Lopes T. C. (2015), A lei do valor e o planejamento econômico de natureza capitalista. 2015. 288 f. Tese. (Doutorado em Economia) - Universidade Federal de Uberlândia, Uberlândia.

12. Ocampo J. A. (2001), Retomar la agenda del desarrollo. Trabalho apresentado na reunião anual da Associação Americana de Economia em Nova Orleans (EUA).

13. Oliveira O. M. (Org.) (2000), Paradigmas das Relações Internacionais. Ed.UNIJUÍ, Ijuí.

14. Pinheiro N. P., Souza L. E. S. de. (2017), A CEPAL como escola de pensamento autônomo: considerações preliminares sobre a tese centro-periferia. Anais do XII Congresso Brasileiro de História Econômica \& 13ª Conferência Internacional de História de Empresas. UFF/ABPHE, Niterói.

15. Sachs I. (2001), A nova agenda de desenvolvimento da CEPAL. Opinião/Estado de São Paulo, http://www.estado.estadao.com. br/editorias (accessed February 05, 2017).

16. Santos B. de S. (2005), Os processos da globalização, In: B. de S. SANTOS (org.), A globalização e as ciências sociais. 3. ed. São Paulo: Cortez Editora, p. 25-102.

17. Santos T. dos (1971), O novo caráter da dependência: grande empresa e capital estrangeiro na América Latina, In: L. PEREIRA (org.), Perspectivas do Capitalismo Moderno: leituras de sociologia do desenvolvimento. Zahar, Rio de Janeiro, p. 185-236.

18. A Teoria da Dependência (2000), Balanço e Perspectiva. Civilização Brasileira, São Paulo.

19. Souza N. de J. de (1993), Desenvolvimento Econômico. Atlas, São Paulo.

20. Sen A. (2000), Desenvolvimento como liberdade. Traduzido por Laura Teixeira Motta. Companhia das Letras, São Paulo.

21. Richardson R. J. (2017), Pesquisa social: métodos e técnicas. 4. d. Atlas, São Paulo.

22. Bhattacherjee A. (2012), Social Science Researche: Principles, Methods, and Practices. 2. ed. Textbooks Collection. USF, Tampa, Florida.

23. Beuren I. (2013), Como Elaborar Trabalhos Monográficos em Contabilidade: Teoria e Prática. 3. Atlas, ed. São Paulo. 